\title{
Urgences
}

\section{Mimes et jardins}

\section{Mario Joubert}

Numéro 4, 2e trimestre 1982

URI : https://id.erudit.org/iderudit/025062ar

DOI : https://doi.org/10.7202/025062ar

Aller au sommaire du numéro

Éditeur(s)

Urgences

ISSN

0226-9554 (imprimé)

1927-3924 (numérique)

Découvrir la revue

Citer ce document

Joubert, M. (1982). Mimes et jardins. Urgences, (4), 63-65.

https://doi.org/10.7202/025062ar

Ce document est protégé par la loi sur le droit d'auteur. L'utilisation des services d'Érudit (y compris la reproduction) est assujettie à sa politique d'utilisation que vous pouvez consulter en ligne.

https://apropos.erudit.org/fr/usagers/politique-dutilisation/
Cet article est diffusé et préservé par Érudit.

Érudit est un consortium interuniversitaire sans but lucratif composé de l'Université de Montréal, l'Université Laval et l'Université du Québec à Montréal. Il a pour mission la promotion et la valorisation de la recherche. https://www.erudit.org/fr/ 
MARIO JOUBERT

\section{Mimes et jardins}


Je me promène vis-à-vis des jardins de hontes Aux visages insolites de mon être $\mathrm{J}$ 'ai le courage de ne plus avoir de courage Aux frontières gloutonneuses de vos pas Encerclant mes ténèbres mes lumières Du pays sans nom et de l'infini L'éternel boit l'aventure de l'amour passage En horizons déchirés de l'âme meurtrie Et le secret devient un acte de foi Dans les rencontres aux mille maux Qu'une folie berce sur son corps Je me promène vis-à-vis des jardins de hontes 
La vie est un mime, je suis sourd. La parole est un labyrinthe de silences qui se pose fécond à l'intérieur des sens. Et le vide devient plein de contact faisant pendant à la vie. Le regard se fait oubli aux yeux des gens.

La vie est un mime qui se pose au regard créateur, car la parole devient silence.

Avant que l'oreille devienne sourde, j'ai entendu les chants de l'automne, c'était mon coeur qui se déchirait. 